\title{
Landscape Restoration and Rehabilitation: A Geocultural Design Approach
}

\author{
Lino Bianco
}

\begin{abstract}
The visual impact of open-pit mineral workings along sloping terrain generates conspicuous scars extending to the surrounding landscape. Such irreversible developments permanently alter the original landform. This is more pronounced in areas of high landscape value. The aim of this paper is to put forward the case for a contextual design of a restoration scheme grounded in the geophysical and cultural elements making up the landscape character and thus complimenting it. This is demonstrated through a case study of Gozo, a picturesque sister island of Malta, known as the island of Calypso after the legendary Homeric nymph, where such quarries have significant visual impact. Based on site contours derived from historical survey sheets and making reference to vernacular cultural features within the surroundings, a restoration and rehabilitation of a disused quarry based on a geocultural approach to landscape design was developed. Prior rehabilitated to sustainable agrarian parcels of land, the site contours were re-introduced together with field boundaries to pre-mineral operational status. This approach is a rational solution derived from rural vernacular architecture and ensures a landscape design solution which reinstates the scenic quality and the aesthetic experience of the area.
\end{abstract}

Index Terms - Landscape restoration, landscape rehabilitation, geocultural landscape, design, visual impact, Gozo.

\section{INTRODUCTION}

Disused open-pit mining operations are a cause of negative impact on the surrounding environs [1]-[3]. They are intrusive on the existing geocultural environs. Indeed quarrying is an activity, so essential for the social well-being of the community, which is hostile and destructive towards the natural habitat of various species and the general environment It is an irreversible development which impinges and depreciates the landscape value [4]. The restoration and rehabilitation of quarries involves making good for the damage generated by such operations through alterative re-use of the land. Visual impact is a paramount environmental concern such as in [5]. The significance of the scenic quality is nowadays recognised by the European Landscape Convention [6]. Quarrying impact in the Maltese islands, an archipelago of a group of low lying islands aligned in a North-West - South-East direction in the central

Manuscript received August 8, 2016; revised October 22, 2016. This work was supported by the Ministry for Gozo, which, at the time of the study was the Parliamentary Secretariat for Gozo within the Office of the Prime Minister, Malta. It had funded the environment impact assessment and the baseline studies forming the basis of this research.

L. Bianco is with the Department of Architecture and Urban Design, Faculty for the Built Environment, University of Malta, Msida MSD 2080, Malta (e-mail: lino.bianco@um.edu.mt).
Mediterranean, is no exception. Malta, the largest, is located $96 \mathrm{~km}$ south of Sicily and $290 \mathrm{~km}$ north of Africa. After mainland Malta, Gozo is the second largest island (Fig. 1). It has a long history of quarrying dating back to the Neolithic period. It supports Ggantija megalithic temple complex, a World Heritage Site [7] dating to circa a millennium prior to the great pyramids of Egypt. The mineral extractive industry accounts for significant irreversible alterations to the island's topography [8].

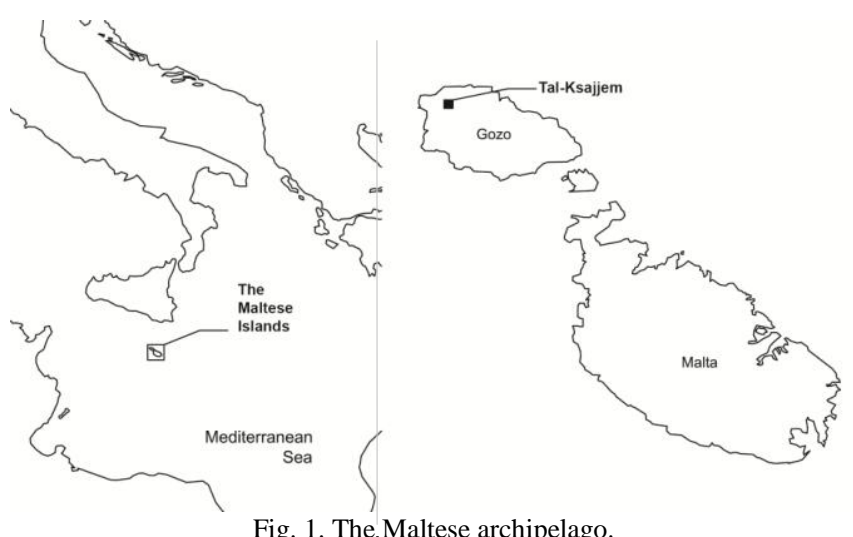

The geological sequence of the Maltese Islands is made up of five lithostratigraphic units. These, in chronological order, are Lower Coralline Limestone, Globigerina Limestone, Blue Clay, Greensand and Upper Coralline Limestone [9]. Industrial mineral extraction is through open-pit mining. Two types of quarries are present, hardstone extracted from Coralline Limestone formations, and softstone extracted from the lower stratum of the Globigerina Limestone formation [10]. The environmental contexts where these quarries are located are diametrically opposite: in mainland Malta, hardstone quarries are located along sides of natural valleys, which are thus highly visible, whilst softstone quarries are along a relatively horizontal terrain, rarely visible from the surrounding environs. In Gozo, hardstone quarries are either on plateaux or along the coast, with minimal visual impact, whilst softstone quarries are along sloping terrain with high visual impact.

Traditionally, quarries along relatively horizontal terrain were rehabilitated for agrarian use, mainly orchards; quarry floors were raised by infilling with inert waste to some metres lower that the surrounding natural topographical levels. According to the Mineral Subject Plan for the Maltese Islands [11], quarries have to reclaimed, once exhausted, for either of the following: agricultural land, commercial orchards, nature conservation uses and informal recreational/touristic facilities. 


\section{BACKGROUND}

\section{A. Geoculture and Landscape}

It has long been recognised that anthropogenic landscapes should address aesthetic values and cultural requisites [12]-[14]. Most landscape restoration to quarries adopts mainly an ecological approach [15]-[20] or a geomorphological approach [21]-[23]. Other approaches have also been adopted such as in [24]-[27]. The ecological approach takes into account the context of the landscape, both natural [28], [29] and cultural [30], in full cognisance of the general public appeal to same [30]-[33].

The geocultural approach being proposed involves the replication of land form to original site contours whilst making use of the main cultural references in the landscape. The geology gives rise to existing topography which supports the natural and cultural heritage. The landscape transformation generated by open-pit mineral workings is re-transformed into a harmonious reconstruction of the landscape profile. It is an artificial landscape addressing the visual impact and after-use. A geocultural approach to landscape restoration ensures post-quarrying, geophysical and culturally sensitive sustainable landscaping design and planning. This leads to the reinstatement of the original landscape value of a given site. Landscape values bridge the gap between the geography and the sense of place [34]-[36].

\section{B. Study Area and Objectives}

The purpose of this paper is to illustrate a restoration and rehabilitation proposal based on the main existing elements of the topography of the landscape, a design grounded in the geophysical parameters of the site and the cultural heritage features in its vicinity. These references are a useful source to develop a sustainable landscape restored to the original site profile and character. The environmental impacts of a disused softstone quarry at Tal-Ksajjem, within the limits of the village of GHarb (coordinates: $36^{\circ} 3^{\prime} 58^{\prime \prime} \mathrm{N}$ and $14^{\circ} 12^{\prime} 45^{\prime \prime} \mathrm{E}$ ), were assessed (Fig. 1, Fig. 2). The natural and rural character of Gozo was acknowledged through the Structure Plan for the Maltese Islands [37]. Nowadays, it is designated to become an ecological island [38]. The study area measured $1 \mathrm{~km}$ diameter centred on the site, an area deemed sufficient for the island which measures $14.5 \mathrm{~km}$ by $7.2 \mathrm{~km}$. The specific objectives were the following:

1) to establish the land-use within the study area to generate enough data for the analysis of the existing landscape character,

2) to identify the location(s) of particular feature(s) in the landscape scenery, plotting them and photographically record them, and

3) to propose a contextual landscape design concept which mitigate the existing visual impact.

\section{Study Context}

The site under study, having an area of approximately $26,000 \mathrm{~m}^{2}$, formed part of a softstone quarry complex which mostly had been reclaimed back to agriculture. Such after-use is an environmental economic asset [39]. Situated in a location of high visual impact on the north-western fringe of the island, it is within the immediate vicinity of major topographic features, both natural and man-made. The significant physical feature is Wied il-Mielah dry valley system. Being one of the largest fluvial systems, it determines to a great extent the type of land use, namely terraced fields, some of which had fallen into disuse. The number of disused softstone quarries located on the lower slopes of the valley's flanks, at present reclaimed for agrarian use, indicates that the area has long been used for open pit mineral extraction.

The quarry is located on a major bend of the valley bed of Wied il-Mielah. From this point northwards, the valley meanders across a relatively open landscape characterised by gently rolling plains and dotted with mesa landforms and associated clay taluses. The landscape is heavily dissected by a number of dry valley systems. Most of the illegal, uncontrolled backfilling on site, a typical scenario triggered by disused quarries [40], was present at the time of the study.

\section{RESEARCH METHODS}

The evaluation of the site was undertaken through a desk study and ground surveys. The former, a semi-qualitative analysis, was based on official ordinance survey sheets, plotted at scale 1:2500, for the years 1957, 1968 and 1993, and the corresponding official aerial photographs (Table I).

Comparative aerial photography and the survey sheets were used:

1) to read the development planning history of the site and the surrounding land uses, and

2) to identify the extent of the landscape character of the area around the quarry.

The factors affecting the interpretation of aerial photos were the scale of the photograph, the shape and shadow of the site, associated features and tone. Difficulty in interpretation increased with decreasing scale. Ta' Pinu Sanctuary, a main touristic landmark, and the masonry bridge (Fig. 3) were the features which provided bearing to identify its location. Landscape features were selected on the basis of being typical to the area of study.

TABLE I: ORDINANCE SURVEY SHEETS AND OFFICIAL AERIAL PHOTOGRAPHS COVERING SITE HISTORY

\begin{tabular}{lcccccccc}
\hline \hline \multirow{2}{*}{ Year } & \multicolumn{2}{c}{1957} & \multicolumn{2}{c}{1968} & \multicolumn{2}{c}{1988} & \multicolumn{2}{c}{1993} \\
& S.S. & Photo & S.S. Photo & S.S. & Photo & S.S. & Photo \\
\hline Ref. Nos. & 6,7, & 182 & 2891 & n.a. & 2891 & 65 & 2891 & 055, strip 50 \\
& 12,13 & & & & & & & 296, strip 51 \\
Scale & 2500 & 8000 & 2500 & n.a. & 2500 & 15000 & 2500 & 4,000 \\
\hline \hline
\end{tabular}

S.S.: ordinance survey sheet; photo: official aerial photo; n.a.: not available.

Through quantitative assessment, the land uses were estimated to establish the elements making up the landscape. Where present in an explicit, consistent manner, they gave character to the landscape. The main features were identified, studied and evaluated to comprehend their inter-relationship and the pattern present in the landscape. Overlaying the various findings, a relationship between the physical components and the perceived sense of place associated with a given particular feature was established. Although ground surveys include an error in the interpretation and estimation of the superficial area for each land use, they were deemed sufficient for the purpose of this study. 


\section{RESULTS}

\section{A. Mapping Land Uses}

Various erosion processes had modified the landscape into a number of mesa landforms and contiguous plains. These had been dissected by Wied il-Mielah. The most widespread land use was dryland agriculture. The morphology of the valley itself had been considerably modified by such activity. The sides of the valley had been transformed into successive levels of terraced fields. Upslope, the field sizes increased in proportion to the intensity of the actual agrarian activity. A number of smaller plots of land, particularly those in the immediate proximity of the site, were fallow and abandoned.
Commercial activity in the area is limited to part-time farming practices with recreational activity focusing on hiking and leisure walks. Built development in the area is concentrated within the boundaries of the village of GHarb and the hamlet of GHammar. The land cover of the study was categorised into four: mineral workings, agrarian land, ecology and urban/semi-urban [41]. The various land uses are stated in Table II and plotted in Fig. 3. From the aerial photos it was evident that, in 1957, mineral extraction already covered half the present size of the quarry. By 1988, it was reclaimed back to agriculture. Although the 1993 aerial photos showed the site as being still cultivated for agricultural purposes, the south-western part had been infilled to the level of the adjacent public road.

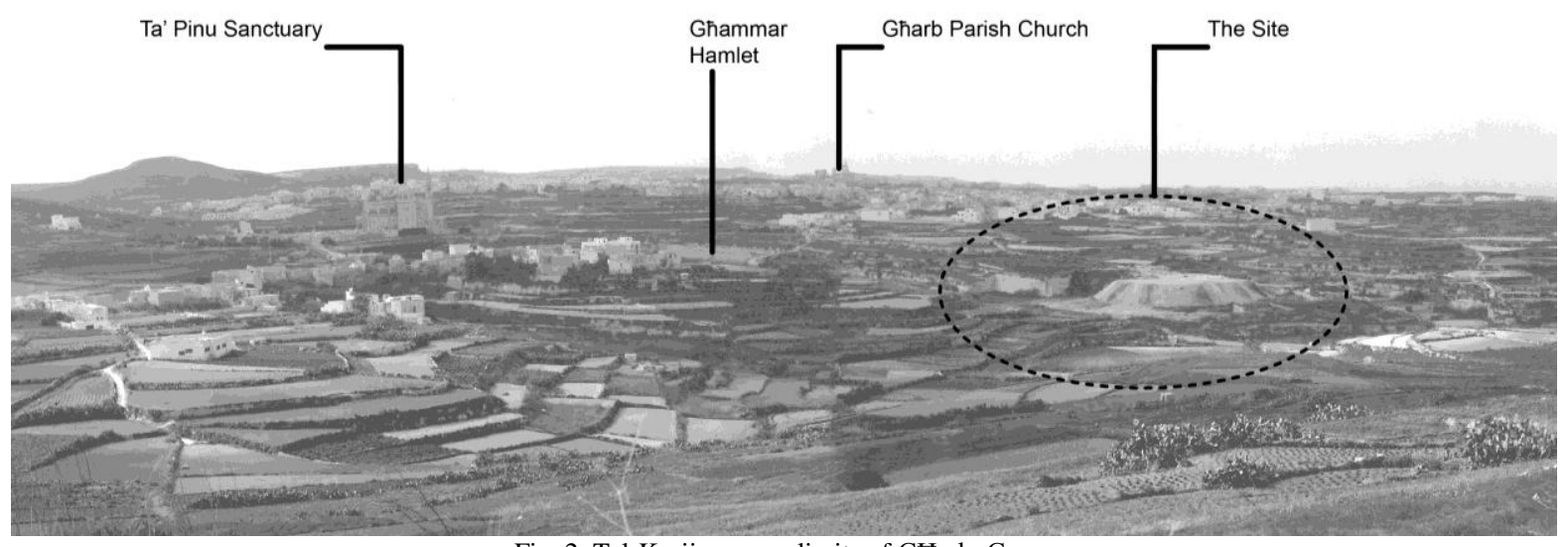

Fig. 2. Tal-Ksajjem area, limits of GHarb, Gozo.

TABLE II: LAND USES WITHIN THE STUDY AREA

\begin{tabular}{lcc}
\hline \hline Land Use Type & Area $\left(\mathrm{m}^{2}\right)$ & Percentage $(\%)$ \\
\hline Mineral workings & & \\
The site & 025,976 & $03.3 \%$ \\
Reclaimed quarries & 016,636 & $02.1 \%$ \\
Agrarian land & & \\
Cultivated & 608,530 & $77.5 \%$ \\
Abandoned & 072,090 & $09.2 \%$ \\
Scraped tracts & 002,919 & $00.4 \%$ \\
Ecology & & \\
Valley Bed & 013,134 & $01.7 \%$ \\
Disturbed ground & 001,167 & $00.1 \%$ \\
Degraded garigue & 001,459 & $00.2 \%$ \\
Urban/Semi-urban & & \\
Settlement & 023,349 & $03.0 \%$ \\
Main access routes & 008,756 & $01.1 \%$ \\
Roads & 011,383 & $01.4 \%$ \\
\hline \hline
\end{tabular}

* Percentage was calculated as a fraction of the total study area.

\section{B. Geological and Hydrological Considerations}

Gozo is composed of tertiary succession of limestones with intervening strata of marls and clays stacked in a simple horizontal fashion [42]. Quaternary deposits capping the whole succession are limited. The succession dates to the Oligo-Miocene age [43]. Different lithologies give rise to contrasting landscapes with the more compact limestone formations giving rise to sharp drops and flat barren plateaux often eroded by karstic action. On the other hand, the marls form a gently rolling landscape whilst the clays are often cultivated by way of terraced fields which characterise most of the Gozitan countryside. The lithostratigraphic outcrops within the study area are the three distinct members of the
Globigerina Limestone Formation: the Upper, the Middle and the Lower. The quarry extracts the Lower Globigerina limestone, locally known as franka. This industrial mineral has been quarried for the erection of building engineering structures since time immemorial [44], [45].

Located within the hydrological catchment of Wied il-Mielah, the geological setting excludes all possibilities that one encounters springs which surge from the perched aquifer, on top of the Blue Clay [46]. The only one present is the Mean Sea Level Aquifer; its potentiometric surface occurs around sea level with a flow pattern directed predominantly towards the coastline.

\section{Pedological and Ecological Considerations}

The predominant type of agriculture is dryland farming. The main agricultural crops are sulla, wheat and barley, legumes and some spring potatoes [47]. The average field size is about 500 to $1000 \mathrm{~m}^{2}$. Most of the rubble walls had fallen into disrepair with a concurrent increase in soil erosion. Using Kubiena classification, surface soil sampling and analysis indicated the presence of Xerorendzina soil, San Biagio Series [47]. Typical topsoil and subsoil depths of San Biagio profiles in Western Gozo are about $20 \mathrm{~cm}$ and $55 \mathrm{~cm}$ respectively [48].

The vegetation of the study area was typical of communities associated with disturbed ground and consisted of resilient species characterised by rapid growth and high fecundity [49]. Such species were favoured in disturbed habitats since they react to changing ecological conditions more swiftly than large, slow-growing ones. All the recorded species on disturbed ground were not listed in the Red Data 
Book [50]. The community of the valley bed was terrestrial rather than aquatic with all present species not listed in the Red Data Book. The exception is Carlina involucrata, a species of restricted distribution in the Mediterranean region [49]. Construction of dams along the floor of the valley led to the accumulation of silt, permitting the invasion by terrestrial species which gradually displaced the freshwater ones characteristic of this habitat.

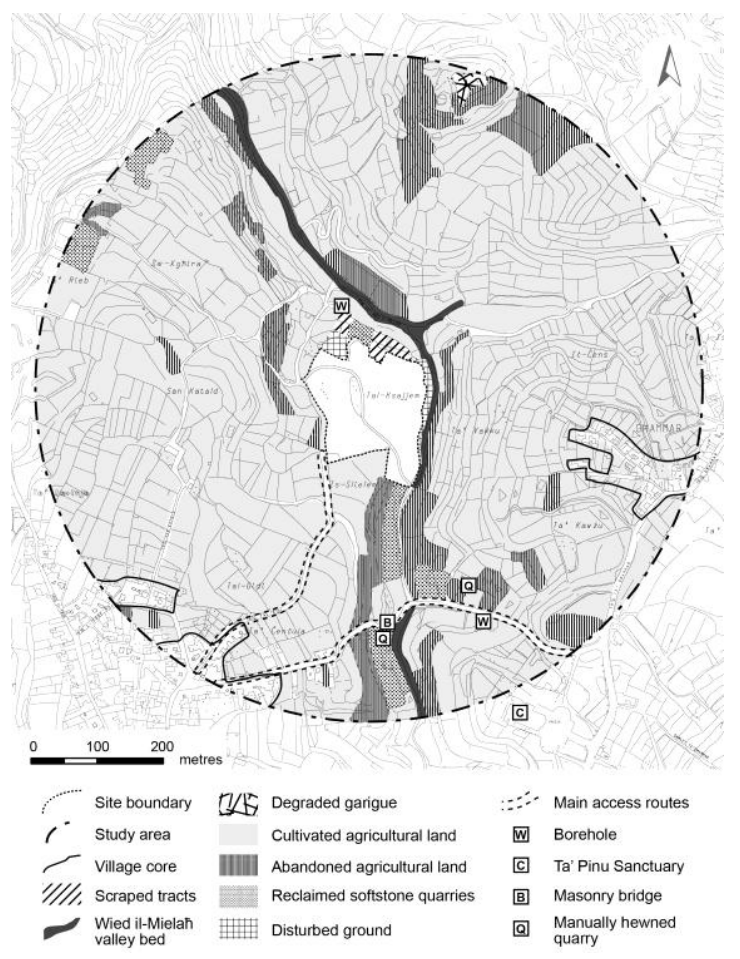

Fig. 3. Land-use map.

Parts of the valley system surrounding the site had suffered substantial environmental and visual degradation. These were worsened by the presence of a run-down access route to the site passing along the valley bed. Other sources of anthropogenic disturbance included dumping of construction waste, spillage of vehicle fuel, leaching of agricultural effluent, construction of dams and entry of alien species into the community.

\section{Cultural Heritage Landscape}

Wied il-Mielah is a single geo-physical context in which a number of anthropogenic interventions through time have contributed to the current cultural landscape [51]. Two historical and cultural landscape features are agriculture and softstone quarries. Agricultural assets are represented by the rubble walls and terraced field systems. Traditionally, given the barren land character of the Maltese islands, terraced fields were formed by covering such land with soil which was retained on site by means of dry-stone rubble walls [52]. Industrial archaeology is represented by a series of shallow and deep quarries. The absence of mechanised cutting marks raises the cultural value of these manmade features [51]. Among these assets there are two old quarries, manually hewned, located along the access route which runs over the masonry bridge.

Although not scheduled, Tal-Ksajjem quarry has a significant landscape value and is of local landscape importance. In spite of weathering, the quarry faces were conspicuous and visible from as far off as Ta' Gordan Hill, $1 \mathrm{~km}$ North-East of the site. Absence of clear management policies and the lack of an acceptable visually sensitive rehabilitation design for the after-use of mineral operations were evident in the picturesque topography of the site.

\section{DISCUSSION}

\section{A. Assessment of Environmental Impacts}

The main characteristics of the study area are land form, land use, elements in the landscape and site access. Site levels ranged from $67 \mathrm{~m}$ to circa $80 \mathrm{~m}$ above mean sea level. When viewed from Ta' Gordan Hill, a popular location with both local and foreign tourists, the site disrupts the harmonious continuity in the terraced, natural landforms. The principal land use is agriculture; terraced fields dominate the landscape. The cultural assets typical of the study area relate to vernacular rural constructions which are protected through the Rubble Walls and Rural Structures Conservation and Maintenance (Amendment) Regulations [53]. Rubble walls are the main elements of the landscape scenery. These regulations specifically define a rubble wall as a dry stone wall, built in loose unhewned or rough-dressed stones. It further states that such a wall has to stand by gravity and friction and without the use of mortar.

The significance of the hydrogeology of the area is highlighted by the presence of a pumping station situated close to Triq ta' Wied il-Mielah. As an ideal aquitard, the Lower Globigerina Limestone can act as a buffer to delay the migration of pollutants from the surface to the Mean Sea Level Aquifer. The wells in the vicinity of the site are vulnerable to pollutants dumped during land filling. Groundwater pollution might have lead to health risks to the community residing at GHarb. Furthermore, losses in water production translate into additional public expense to replace it through other sources. In addition to being detrimental to the flora and fauna in the valley habitat, pollutants might also seep into the adjacent watercourse and end flowing over the Lower Coralline inlier further down the valley, and thus reaching the aquifer at a faster rate.

Western Gozo is rich in dryland farming as the clayey soils would not permit an irrigation regime. Thus, opting for the reclaimed site to be used for such farming was a suitable option which merged with the rest of the landscape. Soil is barren of vegetation during the dry summer months and hence increases the likelihood of soil erosion by wind. The situation is worsened by the heavy autumn rain. Field terracing, contour cultivation and rapid vegetation establishment, reduce erosion. San Biagio Series, the soil likely to have been present on site prior to the commencement of mineral extraction operations, was used in the soil profile of the restored site in order to preserve the surrounding area's homogenous pedology.

Impacts arising from the rehabilitation scheme were minimised by i) relocation of excess construction waste away from the valley system, ii) removal of the existing access road along the valley floor, iii) careful storage of any potential contaminant and iv) selection of native vegetation for landscaping purposes. Excess construction waste arising from 
the proposed rehabilitation was disposed of in a designated location approved by the planning regulator. The disturbance arising from the disposal of waste favours the growth of opportunistic annuals, both native and alien, with consequent displacement of native species.

Visible cultural features relating to mineral operations, such as quarry marks, should be recorded prior to being buried under the proposed restoration. One, low cost recording approach is through photogrammetric methods that would allow eventual reconstitution of data. From a geocultural landscape perspective, the major concern in the restoration and rehabilitation of Tal-Ksajjem quarry was its visual impact. On such a touristic and ecological island, the quarry has degraded the aesthetic experience that visitors enjoy.

\section{B. Restoration Proposal}

The design considerations for landscape restoration are given in Table III. It involved infilling with inert building construction waste and reclaiming the site for agriculture purposes. Where data regarding site contours, terracing and fields boundaries was available from survey sheets, it was incorporated into the design proposal (Fig. 4); where absent, the position of contours and field boundaries were designed through extrapolating the information contained in the survey sheets and aerial photographs. Since the location is along a slope, fields usually follow the natural contours of the land. Where data was not available, field sizes were kept in the range of the average present within the study area, namely 500 to $1000 \mathrm{~m}^{2}$. Such sizes are more effective against soil erosion.

No aerial photographs prior 1957 are available. The 1957 survey sheet does not distinguish between original terracing and scrapped land. In either case, it is indicative of the natural topographical layout of the site. Thus, this survey sheet was used as the conceptual layout of the proposed rehabilitation scheme.

The 1968 survey sheet was used to identify the contours of the land and their respective position above mean sea level. A typical vernacular wall along the valley bed of Wied il-Mielah, part of which had collapsed, had been used to develop the design of the rubble walls used in the restoration scheme (Fig. 5)

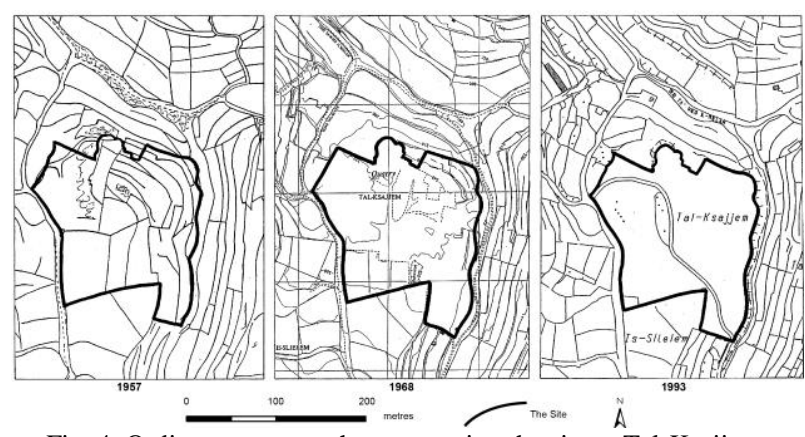

Fig. 4. Ordinance survey sheets covering the site at Tal-Ksajjem.

The proposed phasing of the restoration profile involved five stages. Each stage, together with the activity involved and the recommended intervention is stated in Table IV. The restored site has three distinct divisions which, starting from the lowest, are the inert fill, subsoil and topsoil. For sustaining the restored profile, the proposed after-use was agrarian activity. Vegetation reduces risk of soil erosion. The rubble walls had to be regularly maintained both for maximum soil preservation and for aesthetic reasons. The restored profile of the site and a visual of same are shown in Fig. 6 and Fig. 7 respectively.
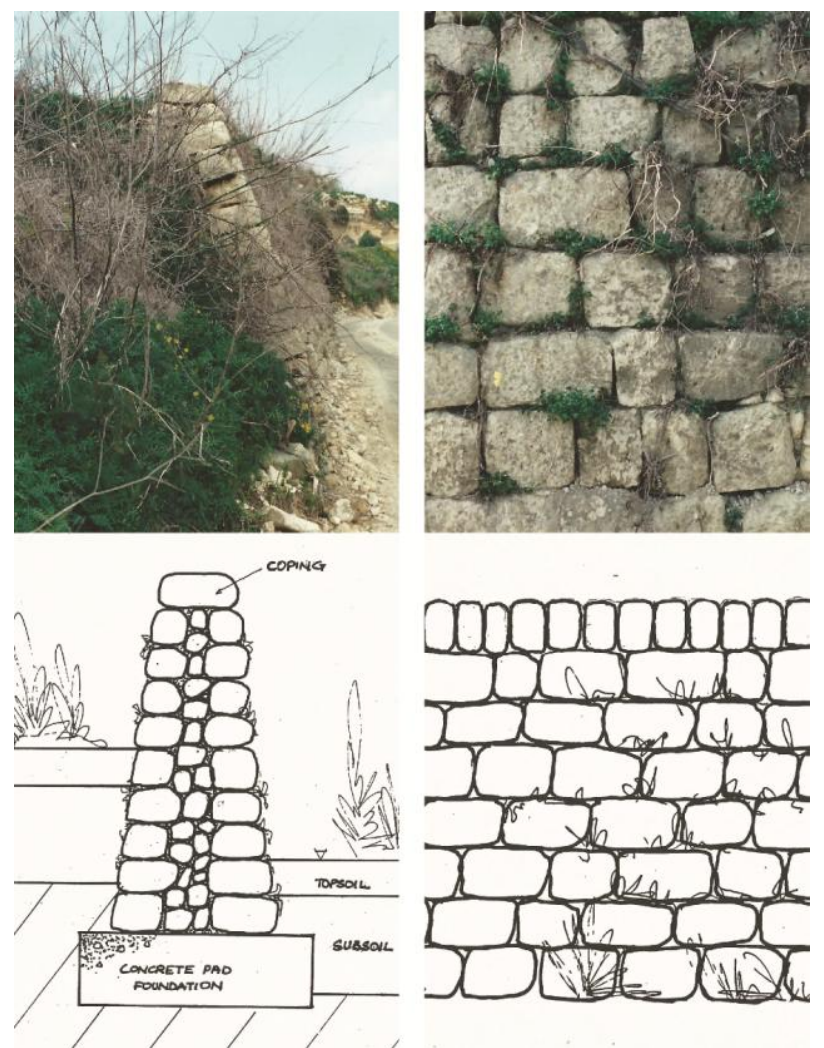

Fig. 5. Section (top left) and elevation (top, right) of a typical rubble wall along the valley bed of Wied il-Mielah. These were used to prepare the respective section (bottom, left) and elevation (bottom, right) respectively.

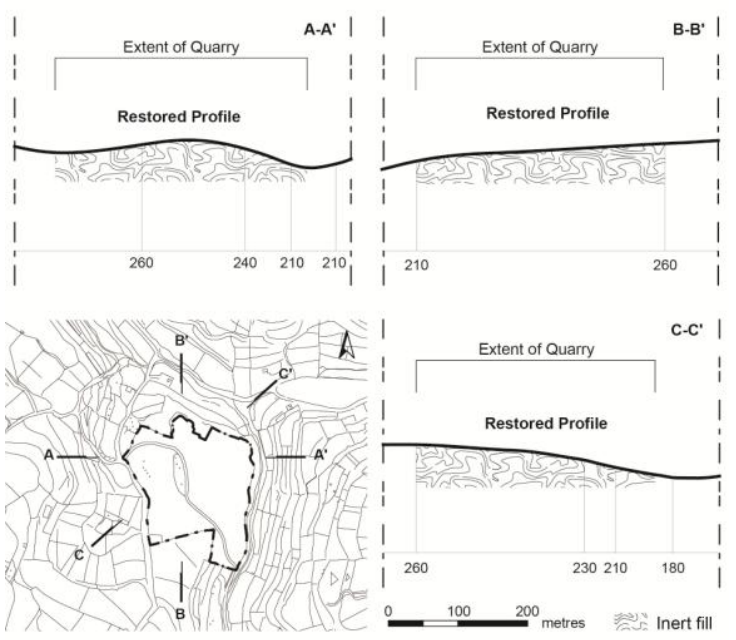

Fig. 6. Profile design of the restoration landscape.

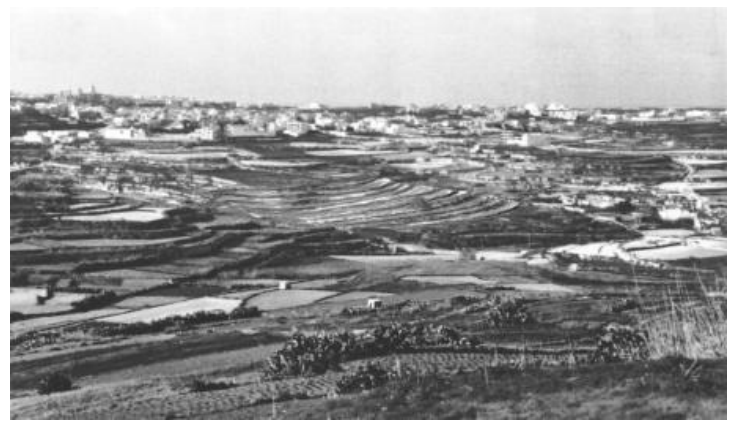

Fig. 7. Visual of the restored landscape. 
Assessment of water and land pollution through environmental audit of the restored phase is an important consideration [54]. Given the high porosity of the restored site, preventive measures against leaching of substances into the aquifer were recommended to minimise the risk of pollution of ground water from agrarian and allied activities. Irrigation techniques were limited to the drip-type. Another recommended measure was the adoption of organic farming techniques. The public perception of organic farming at the time was that it promotes the cultivation of plants and agricultural products without making use of pesticides and/or chemicals, thus generating confidence of healthier relation between farmers, consumers and the environment [55].

TABLE III: DESIGN CONSIDERATIONS FOR LANDSCAPE RESTORATION

\begin{tabular}{|c|c|c|}
\hline Parameter & Existing Considerations & Proposed Considerations \\
\hline Land use & Dryland agriculture predominates & $\begin{array}{l}\text { Restore site back to agrarian uses to typical field sizes of } 500 \text { to } \\
1000 \mathrm{~m}^{2}\end{array}$ \\
\hline Geology & Lower Globigerina Limestone outcrops on site & Photographically record quarry faces prior to land filling \\
\hline Hydrogeology & $\begin{array}{l}\text { Lower Globigerina Limestone is an aquitard which } \\
\text { delays percolation to mean sea level aquifer }\end{array}$ & $\begin{array}{l}\text { Compacted inert waste construction material helps retarding } \\
\text { percolation to the quarry base and to the adjacent watercourse }\end{array}$ \\
\hline Pedology & $\begin{array}{l}\text { Xerorendzina soil (San Biagio Series); typical depth of } \\
\text { topsoil and subsoil are } 20 \mathrm{~cm} \text { and } 50 \mathrm{~cm} \text { respectively }\end{array}$ & $\begin{array}{l}\text { Topsoil and subsoil profiles will be reconstructed to the average } \\
\text { current depths existing in fields within the study area. Soils (San } \\
\text { Biagio Series) will be utilised }\end{array}$ \\
\hline Ecology & $\begin{array}{l}\text { Wied il-Mielah system, one of the largest fluvial systems } \\
\text { on the island, bounds the site }\end{array}$ & $\begin{array}{l}\text { Introduce native vegetation to help consolidate the reconstructed soil } \\
\text { levels and prevent infilled material reaching the valley bed }\end{array}$ \\
\hline Cultural heritage & $\begin{array}{l}\text { Rubble walls, protected at law, are the predominant } \\
\text { vernacular cultural heritage within the study area }\end{array}$ & $\begin{array}{l}\text { Reconstructed rubble walls in traditional construction technique to } \\
\text { complement the existing geocultural landscape }\end{array}$ \\
\hline Visual impact & Site located in a panoramic landscape & $\begin{array}{l}\text { Reconstructed rubble walls, whilst serving as retaining structures, will } \\
\text { visually compliment the surrounding environs of significant landscape } \\
\text { value }\end{array}$ \\
\hline
\end{tabular}

TABLE IV: PHASING OF THE RESTORATION PROFILE

\begin{tabular}{|c|c|c|}
\hline & Activity & Recommended Intervention \\
\hline Phase 1 & Filling the quarry with inert fill material & $\begin{array}{l}\text { Fill compacted to prevent subsidence, decrease porosity and permeability, and increase capacity } \\
\text { of fill on site; fill is to be to the levels indicated }\end{array}$ \\
\hline Phase 2 & $\begin{array}{l}\text { Compaction of inert material to original } \\
\text { contour level less depth of subsoil and } \\
\text { topsoil }\end{array}$ & $\begin{array}{l}\text { At top of fill, cast concrete strip foundation and erect a random dry-stone rubble walls along the } \\
\text { established and/or designed location of field boundaries; place the subsoil simultaneously on the } \\
\text { lower sides of the terraces }\end{array}$ \\
\hline Phase 3 & $\begin{array}{l}\text { Subsoil placed on the compacted inert } \\
\text { material to a depth of about } 55 \mathrm{~cm}\end{array}$ & $\begin{array}{l}\text { Use of earth moving equipment; the lower sides of the terraces should be stabilised by stonework; } \\
\text { these should be constructed simultaneously with subsoil deposition }\end{array}$ \\
\hline Phase 4 & $\begin{array}{l}\text { Topsoil placed on the subsoil to a depth of } \\
\text { about } 20 \mathrm{~cm} \text { and levelled }\end{array}$ & $\begin{array}{l}\text { Use of scrapers is recommended for this purpose; contour cultivation by rotary cultivator soon } \\
\text { after post levelling of the topsoil minimises erosion; if serious compaction problems are noted, } \\
\text { deep tillage is recommended }\end{array}$ \\
\hline Phase 5 & $\begin{array}{l}\text { Vegetation rapidly carried out to act as an } \\
\text { effective protection against soil erosion }\end{array}$ & $\begin{array}{l}\text { A temporary cover of seeded grass holds the soil until dryland farming; vegetation binds soil } \\
\text { particles together, breaks the raindrop impact, and prevents wind erosion when soil moisture } \\
\text { content is low }\end{array}$ \\
\hline
\end{tabular}

\section{CONCLUSION}

This paper attempted to identify a design methodology and outline a contextual restoration proposal for beneficial, sustainable after-use whilst mitigating the significant visual scar in the landscape generated by the quarry operations. It put forward a case for the restoration and rehabilitation of a disused quarry, effectively a prototype for similar natural and cultural landscape settings.

The restoration and rehabilitation of Tal-Ksajjem quarry is a case study which illustrates the applicability and suitability of this approach. The restored and rehabilitated site is a contextual architectural landform solution for a terraced, highly visible landscape with rural vernacular heritage features. The restored site and the consequent visual impact emerged from the link between the physical components and the perceived sense of place of the particular, predominant element present in the landscape, terraced fields. They were re-established, and boundaries to same re-introduced, along the site contours existing prior commencement of mineral operations. Dry stone masonry rubble walls were introduced both for aesthetic and functional, soil retaining reasons. The restoration proposal was grounded in the geophysical and cultural heritage contexts of the site. It reflected the landscape character of the area thus balancing out the existing negative landscape and visual impacts; as intended, it enhanced the site, once infilled, and re-established continuity with the surrounding landscaping. Reinstatement to agrarian after-use reaps economic benefit which ensures that this continuity is maintained.

The restoration and rehabilitation of disturbed, originally terraced, natural topography, effectively involving the reconstruction of the original site profile, reinstates the landscape value of the site. Given the agrarian nature of the physical geographical context, the geocultural design approach leads not only to visually restoring the landform but serves also to an aesthetical, complimentary rehabilitation of the site for beneficial after-use.

\section{REFERENCES}

[1] Department of the Environment, Environmental Effects of Surface Mineral Workings, London: Her Majesty's Stationery Office, 1991.

[2] C. Lin, X. Tong, W. Lu, L. Yan, Y. Wu, C. Nie, C. Chu, and J. Long, "Environmental impact of surface mining on mined lands, affected streams and agricultural lands in the Dabaoshan mine region, Southern China," Land Degradation and Development, vol. 16, pp. 463-474, 2005.

[3] T. Milgrom, "Environmental aspects of rehabilitating abandoned quarries: Israel as a case study," Landscape and Urban Planning, vol. 87 , pp. $172-179,2008$ 
[4] D. C. Kaliampakos and A. A. Mavrikos, "Introducing a new aspect in marble quarry rehabilitation in Greece," Environmental Geology, vol. 50, pp. 353-359, 2006.

[5] D. C. Mouflis, I. Z. Gitas, S. Iliadou, and G. H. Mitri, “Assessment of the visual impact of marble quarry expansion (1984-2000) on the landscape of Thasos island, NE Greece," Landscape and Urban Planning, vol. 86, pp. 92-102, 2008.

[6] Council of Europe, European Landscape Convention, European Treaty Series No. 176, Florence: Council of Europe, 2000.

[7] UNESCO, World Heritage List: Megalithic Temples of Malta. Available: http://whc.unesco.org/en/list/132

[8] R. Balm, "Big holes in small places - The stone quarrying dilemma in the Maltese islands," Geography, vol. 81, no. 1, pp. 82-86, 1996.

[9] Office of the Prime Minister, Geological Map of the Maltese Islands: Malta, Malta: Oil Exploration Division, 1993

[10] L. Bianco, "The industrial minerals of the maltese islands," Hyphen, vol. 7, no. 3, pp. 111-118, 1995.

[11] Malta Environment and Planning Authority, Minerals Subject Plan for the Maltese Islands 2002: Final Report, Malta: Entec UK Ltd, 2003.

[12] W. Nohl, "Sustainable landscape use and aesthetic perception Preliminary reflections on future landscape aesthetics," Landscape and Urban Planning, vol. 54, pp. 223-237, 2001.

[13] Ch. Haaren, "Landscape planning facing the challenge of the development of cultural landscapes," Landscape and Urban Planning, vol. 60 , pp. 73-80, 2002.

[14] R. Dulias, "Landscape planning in areas of sand extraction in the Silesian Upland, Poland," Landscape and Urban Planning, vol. 95, pp. 91-104, 2010.

[15] A. D. Bradshaw and M. J. Chadwick, The Restoration of Land: The Ecology and Reclamation of Derelict and Degraded Land, Oxford: Blackwell, 1980.

[16] C.Y. Jim, "Ecological and landscape rehabilitation of a quarry site in Hong Kong," Restoration Ecology, vol. 9, no. 1, pp. 85-94, 2001.

[17] A. D. Bradshaw, "Introduction and philosophy," in Handbook of Ecological Restoration. Volume 1: Principles of Restoration, M. R. Perrow and A. J. Davy, Eds. Cambridge: Cambridge University Press, pp. 3-9, 2002.

[18] R. C. Corry, R. Lafortezza, and R. D. Brown, "Ecological functionality of landscapes with alternative rehabilitations of depleted aggregates sites," International Journal of Mining, Reclamation, and Environment, vol. 24, pp. 216-232, 2010

[19] C. Y. Jim, "Ecological and landscape rehabilitation of a quarry site in Hong Kong," Restoration Ecology, vol. 9, no. 1, pp. 85-94, 2001.

[20] Z. Naveh, "From biodiversity to ecodiversity: A landscape- ecology approach to conservation and restoration," Restoration Ecology, vol. 2 , no. 3, pp. 180-189, 1994.

[21] P. Gagen and J. Gunn, "A geomorphological approach to limestone quarry restoration," in Geomorphology in Environmental Planning, J. M. Hooke, Ed. New York: Wiley, 1988, pp. 121-142.

[22] P. Gagen, J. Gunn, and D. Bailey, "Landform replication experiments on quarried limestone rock slopes in the English Peak District," Zeitschrift für Geomorpholodie Supplement, vol. 87, pp. 163-170, 1993.

[23] J. Gunn and D. Bailey, "Limestone quarrying and quarry reclamation in Britain," Environmental Geology, vol. 21, pp. 167-172, 1993.

[24] M. Marignani, D. Rocchini, D. Torri, A. Chiarucci, and S. Maccherini, "Planning restoration in a cultural landscape in Italy using an object-based approach and historical analysis," Landscape and Urban Planning, vol. 84, no. 1, pp. 28-37, 2008.

[25] I. Davidson, M. Sheahan, and R. Thackway, "An innovative approach to local landscape restoration planning: Lessons from practice," Ecological Management \& Restoration, vol. 12, no. 3, pp. 175-188, 2011.

[26] D. I. Rappaport, L. R. Tambosi, and J. P. Metzger, "A landscape triage approach: combining spatial and temporal dynamics to prioritize restoration and conservation," Journal of Applied Ecology, 2015, vol. 52, no. 3, pp. 590-601, 2015.

[27] P. Venodha, "Landscape degradation and restoration - A planning approach," International Journal of Environmental Science and Development, vol. 7, no. 3, pp. 229-233, 2016.

[28] R. C. Corry, R. Lafortezza, R. D. Brown, N. Kenny, and P. J. Robertson, "Guiding ecological restoration with contextual landscape information: An approach for pits and quarries in Ontario," Ecological Restoration, vol. 26, pp. 120-127, 2008.

[29] A. Bradshaw, "The use of natural processes in reclamation Advantages and difficulties," Landscape and Urban Planning, vol. 51 , no. 2-4, pp. 89-100, 2000
[30] R. L. Ryan, P. H. Gobster, R. C. Corry, R. Lafortezza, and R. D. Brown, "Cultural acceptability of alternative pit and quarry rehabilitations," Ecological Restoration, vol. 29, no. 1, pp. 64-72, 2011.

[31] R. B. Hull, "A people-centered approach to designing and managing restoration projects: Insights from understanding attachment to urban natural areas," in Restoring Nature: Perspectives from the Social Sciences and Humanities, P. H. Gobster and R. B. Hull, Eds Washington DC: Island Press, 2000, pp. 209-228.

[32] D. C. Kaliampakos and M. E. Menegaki, "Bridging the gap between quarrying activity and the public: a case study in Athens, Greece," International Journal of Surface Mining Reclamation and Environment, vol. 15, no. 4, pp. 257-266, 2001.

[33] C. Oosten, "Restoring landscapes - Governing place: A learning approach to forest landscape restoration," Journal of Sustainable Forestry, vol. 32, no. 7, pp. 659-676, 2013.

[34] G. Brown, "Mapping spatial attributes in survey research for natural resource management: methods and applications," Society and Natural Resources, vol. 18, no. 1, pp. 17-39, 2005.

[35] G. Brown, "Mapping landscape values and development preferences: A method for tourism and residential development planning," International Journal of Tourism Research, vol. 8, no. 2, pp. 101-113, 2006.

[36] G. Brown and C. Raymond, "The relationship between place attachment and landscape values: Toward mapping place attachment," Applied Geography, vol. 27, pp. 89-111, 2007.

[37] Planning Services Division, Structure Plan for the Maltese Islands Draft Final, Malta: Ministry for Development of Infrastructure, 1990.

[38] Government of Malta. (2015). Strategic Planning for Environment and Development. Malta. [Online]. Available: http://www.mepa.org.mt/Documents/FinalVersion.pdf

[39] J. B. Muscat, "Agriculture and waste management: An environmental perspective," Waste Management and a Viable Economy: Proceedings APS Seminar, Malta: Media Centre Print, 2008, pp. 69-83.

[40] D. C. Kaliampakos, "Rehabilitation of an abandoned quarry used as uncontrolled landfill," International Journal of Surface Mining Reclamation \& Environment, vol. 12, no. 2, pp. 61-65, 1998.

[41] L. Bianco and D. Theuma, "Land use," Environmental Planning Statement: Rehabilitation of Disused Softstone Quarry at Tal-Ksajjem, l/o GHarb, Gozo, EIA Coordinator. Malta: Lino Bianco \& Associates, 1997.

[42] H.P.T. Hyde, The Geology of Maltese Islands, Malta: Lux Press, 1955.

[43] H. M. Pedley, M. R. House, and B. Waugh, "The geology of the pelagian block: The Maltese islands," The Ocean Basins and Margins, Volume 4B: The Western Mediterranean, New York and London: Plenum Press, vol. 4B, pp. 417-433, 1978.

[44] L. Bianco, "Geocultural activity in seventeenth and eighteenth century Malta," GeoJournal, vol. 48, no. 4, pp. 337-340, 1999.

[45] J. Q. Hughes, The Building of Malta during the period of the Knights of St John of Jerusalem, London: Alec Tiranti, 1967.

[46] T. O. Morris, The Water Supply Resources of Malta, Malta: The Government of Malta, 1952.

[47] J. Muscat, "Soils," Environmental Planning Statement: Rehabilitation of Disused Softstone Quarry at Tal-Ksajjem, l/o GHarb, Gozo, EIA Coordinator. Malta: Lino Bianco \& Associates, 1997.

[48] D.M. Lang, Soils of Malta and Gozo, London: Her Majesty's Stationery Office, 1960.

[49] S. Lanfranco, "Ecology," in Environmental Planning Statement: Rehabilitation of disused softstone quarry at Tal-Ksajjem, l/o GHarb, Gozo, L. Bianco, EIA Coordinator. Malta: Lino Bianco \& Associates, 1997.

[50] P. J. Schembri and J. Sultana, Red Data Book for the Maltese Islands, Valletta: Department of Information, 1989.

[51] A. Pace, "Cultural heritage," Environmental Planning Statement: Rehabilitation of Disused Softstone Quarry at Tal-Ksajjem, l/o GHarb, Gozo, EIA Coordinator. Malta: Lino Bianco \& Associates, 1997.

[52] J. Tonna, "Malta," Encyclopaedia of Vernacular Architecture of the World, Cambridge: Cambridge University Press, 1997, pp. 1560-1562.

[53] Laws of Malta, Legal Notice 169 of 2004: Rubble Walls and Rural Structures Conservation and Maintenance (Amendment) Regulations, 2004.

[54] A. P. Economopoulos. (1993). Assessment of sources of air, water, and land pollution. A guide to rapid source inventory techniques and their use in formulating environmental control strategies. Part One: Rapid Inventory Techniques in Environmental Pollution. Geneva: World Health Organisation. [Online]. Available: http://apps.who.int/iris/bitstream/10665/58750/1/WHO_PEP_GETN ET 93.1-A.pdf 
[55] The Times (of Malta), February 27, 1997, p. 23.

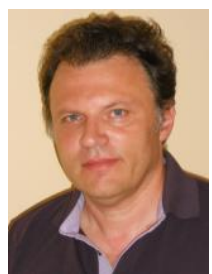

Lino Bianco is a resident academic at the Department of Architecture and Urban Design, Faculty for the Built Environment, University of Malta, Msida MSD 2080, Malta and visiting professor at the Department of Urban Planning, Faculty of Architecture, University of Architecture, Civil Engineering and Geodesy (UACEG), Sofia. In 1997, he set up Lino Bianco \& Associates, a consultancy firm majoring in architecture and environmental management and planning.

He received his B.A. in philosophy and humanistic studies (1987) from the Institute of Philosophy and Humanistic Studies, Malta, B.E.\&A.(Hons) in architecture and building engineering (1992) from the University of Malta, M.Sc. in industrial mineralogy (1993) from the University of Leicester, M.Sc. in architectural history (1995) from The Bartlett Graduate School, University College London. He obtained his Ph.D. in architecture and politics (2011) from the UACEG. He has published several papers in peer-reviewed journals, co-edited a special issue of the Mediterranean Journal of Human Rights (vol. 14, no.1, 2010), and authored over 250 technical reports.

Prof. Bianco is a Eur. Ing. (FEANI), a fellow of the Royal Society of Arts (London) and of the Geological Society (London). He is a professor of the International Academy of Architecture. In 2015, he was conferred professor honoris causa by the Georgian Technical University, Tbilisi, in recognition for his contributions to architectural practice and education. 